http://jmscr.igmpublication.org/home/ ISSN (e)-2347-176x ISSN (p) 2455-0450

crossref DOI: https://dx.doi.org/10.18535/jmscr/v9i9.24

\title{
Knowledge, Attitudes and Practices (KAP) towards COVID-19 and importance of Face Masks: A cross-sectional study
}

\author{
Authors \\ Mortuza Begum*1, Adnan Bacha², Mohammad Shahbaz ${ }^{3}$, Sara Farahnaj ${ }^{4}$, \\ Md. Akram Hossain ${ }^{5}$, ASM Saifuddinv Nahid ${ }^{6}$ \\ ${ }^{1}$ MBBS, FCPS. Junior Consultant, Department of Obs and Gynae, Chittagong Medical College and \\ Hospital, Chattogram, Bangladesh \\ ${ }^{2}$ MBBS, MS. Assistant Professor, Department of Surgery, Southern Medical College and Hospital, \\ Chattogram, Bangladesh \\ ${ }^{3}$ MBBS, MCPS, Junior Consultant Medicine, Lama Upazila Health Complex, Banderban, Chattogram, \\ Bangladesh \\ ${ }^{4}$ MBBS, MPH, Assistant Professor, IAHS, Chattogram, Bangladesh \\ ${ }^{5}$ MBBS, D-Card, Senior Consultant,Chittagong General Hospital, Chattogram, Bangladesh.
}

${ }^{6}$ MBBS, D-Ortho, Assistant Professor, Department of Orthopedics, Southern Medical College and Hospital,

Chattogram, Bangladesh

*Corresponding Author

Dr Mortuza Begum

Junior Consultant, Department of Obs and Gynae, Chittagong Medical College and Hospital, Chattogram, Bangladesh

\section{Abstract}

Background: Severe Acute Respiratory Syndrome Coronavirus-2 (SARS-CoV-2) has accursed the world since December 2019 when it was first diagnosed in Wuhan, China. As it quickly spread to almost all the corners of the world, WHO later declared it as a global pandemic. Effective non pharmaceutical measures to control it, depends upon the knowledge and practice of basic principles of hygiene and use of facemasks. Hence educating public about it has an immense role in controlling this contagious disease.

Material and Methods: This cross-sectional study was conducted in Chittagong during June 2020 to December 2020 with a study population of 1489 participants. Adults with good physical and mental condition, and those who agreed to participate were included while unwilling and sick people were excluded from the study.

Results: Out of 1489 participants, the mean age was $28.81 \pm 8.64$ years with range from 12 to 70 years. More than half $(51 \%)$ of the participants were female and about $773(51.9 \%)$ participants had completed above X education level. Knowledge about the disease, its causative agent, main symptoms, ultimate fate and its mode of transmission was considerably high. The majority of the participants were accustomed of the preventive measure such as social distancing, isolation of the patients, home quarantine and avoidance of large gatherings. Knowledge directly affected both attitude and practices as the survey revealed that the majority (88.72\%) of the participants achieved a good knowledge-attitude score and 78.44\% achieved a good knowledge-practice score. Overall achieved knowledge score regarding the importance of the use of face masks translated on attitude and practices.

Conclusion: Our findings insinuated that Bangladeshi population substantiated a decent knowledge about COVID19 and knowledge about the importance of facemasks was above par and that too translated on attitude and practices. Hence widespread targeted health education programme that incorporates considerations of KAP modifying factors is further needed to prevent subsequent waves of the infection.

Keyword: Attitude; Corona virus; COVID-19; Face Masks; KAP study; Knowledge; Practice. 


\section{Introduction}

Coronavirus disease 2019 (COVID-19) is a viral illness caused by the novel coronavirus which belongs to a large family of ribonucleic acid (RNA) viruses, and is now called Severe Acute Respiratory Syndrome Coronavirus 2 (SARSCoV-2; formerly called 2019-nCoV). COVID-19 is an emerging respiratory tract infection, with a wide spectrum extending from asymptomatic to mild symptoms as of the common cold, to more serious diseases, such as Middle East Respiratory Syndrome (MERS-CoV) and Severe Acute Respiratory Syndrome (SARS-CoV) ${ }^{(1,2)}$. The main symptoms of COVID-19 have been identified as fever, dry cough, sore throat, loss of taste and smell, fatigue, myalgia, headache, shortness of breath, dyspnoea and chest pain ${ }^{(3,4)}$. COVID-19 virus can be transmitted either by direct contact with an infected person or by indirect contact with surfaces in the immediate environment or with objects used by the infected person.It is characterized by rapid transmission from the mouth or nose in the form of larger respiratory droplets $(>5-10 \mu \mathrm{m})$ to smaller aerosols $(<5 \mu \mathrm{m})$ when the patient coughs, sneezes, sings or even breathes, and hence can occur by close contact (within 1 meter) of the infected person ${ }^{(5,6)}$.

It was first discovered in December 2019, in Wuhan city, Hubei Province, China from where it almost spread to all the counties of the world in a wink $^{(1,2)}$. On January 30, 2020, the World Health Organization (WHO) declared that the outbreak of COVD-19 constituted a Public Health Emergency of International Concern (PHEI C), calling for countries to take imperative action against the rapid spread of the virus ${ }^{(6)}$. Later, the WHO declared COVID-19 a "global pandemic"(7). As on 15 May 2021, there have been 161, 513, 458 confirmed cases of COVID-19, including 3,352,109 deaths, reported to WHO from 212 countries/territories/areas ${ }^{(8)}$. Bangladesh announced the first three cases of COVID-19 on March 8, 2020 and the infection rates remained low until the end of March, but a dramatic rise in cases began in April 2020, and just by April 30, the total number of confirmed cases raised to 7667 (with 168 deaths) $^{(9)}$.

There is no clinically proven effective treatment for COVID-19 as of yet, and efficacy of vaccine has a big question mark, moreover to vaccinate all the people is an uphill task, that too for low and middle income countries like Bangladesh. In this situation to have an effective control, having knowledge about the epidemiological evidence of the disease, including its transmission dynamics, epidemic doubling time, and reproductive frequency, basic hygienic principles and importance of using face masks is therefore, of vital importance ${ }^{(10)}$. To achieve an ultimate success against this deadly disease, commitment to these control measures is absolutely necessary. According to the KAP theory, this is generally affected by their knowledge, attitude, and practices (KAP) concerning COVID-19 ${ }^{(11,12)}$. Public education is considered as one of the most important measures that can help control the diseases, as has been in the case regarding SARS $^{(13)}$. Amidst pandemics, educating, engaging, intriguing and mobilizing the public to become active participants may help achieve public health emergency preparedness and reduce the overall population's vulnerability ${ }^{(14)}$. When people collectively engage in preventive behaviors like practicing personal hygiene by wearing face masks, using hand sanitizers, regular washing of hands, and maintaining social distance, it is possible to control the spread of the disease. Studies highlight that the individual behaviors may dramatically decrease morbidity and mortality rates of COVID-19 ${ }^{(15,16)}$. Recent studies on COVID-19 revealed that knowledge, perceived controllability, optimistic beliefs, emotion, and risk perception might all account for precautionary actions of the public ${ }^{(10)}$. To date, several KAP studies have examined the associations of knowledge with attitudes or practices beyond understanding the prevalence of each. The results of these previous studies revealed that a higher level of knowledge is positively related to the practice of preventive 
measures, and attitudes also associate positively with preventive behaviors ${ }^{(17-20)}$. Therefore, a routine practice of precautionary behaviors among the public must become the new status quo.

\section{Materials and Methods}

This cross-sectional study was conducted among the adult population across different Medical Colleges and Mass people in Chittagong, Bangladesh during June'2020 to December'2020. A total of 1507 participants were interviewed, and 18 were rejected because of incomplete information or failing to meet the inclusion criteria. Ultimately 1489 participants were considered, all of whom were in a good physical and mental condition (in case of self-administered and face to face interview), who agreed to participate were included in the study. Exclusion criteria included unwillingness and sickness. Considering the special situation that the pandemic had created, it could not be possible to conduct a fully community based survey with a nationally representative sample. In the rural areas a random sampling technique was adopted while as in apartment buildings, questionnaire sets were distributed and the data was collected using a structured questionnaire. The questionnaire although set in English, was translated into Bangla so that the study population can have a better understanding of the questions. It was pre-tested among a cross section of participants to ensure the clarity of questions, reduce bias if any and eliminate the ambiguity. The questionnaire was designed/constructed to collect socio-demographic characteristics that included gender, age, education, occupation and religion of the participants. Knowledge about COVID-19 was assessed by 36 factual statements about the disease, its nature and mode of transmission, high risk population, symptoms of the disease, availability of vaccine, specific treatment, preventive measures, quarantine period, social distancing and incubation period of the disease. Knowledge, attitude and practices related to importance of face masks for the prevention and control COVID-19 was assessed by separate set of questions. At the very outset of the interview, the participants were informed about the purpose of the study, and were given a choice to or not to respond. The consent was obtained from each participant before starting the interview or answering the questionnaire in written. Descriptive statistics including percentages, means, and standard deviations were calculated. Attitudes and practices in relation to knowledge were assessed with independent samples t-test, Chi-square test as appropriate. To identify the factors associated with knowledge, multivariable linear regression analysis was performed, using all of the demographic variables as independent variables and knowledge status as the outcome variable. To identify factors associated with attitudes and practices, binary logistic regression analyses were performed, selecting the factors with a backward stepwise method. To quantify the associations between variables and knowledge, attitude and practices statistical significance was set to 0.05 or less and a confidence interval of 95\% for all analyses. Data entry and statistical analyses were performed using Statistical Package for Social Science Programme for Windows (Version 23.0).

\section{Results}

Table 1 shows that out of 1489 participants, the mean age was $28.81 \pm 8.64$ years with range 12 to 70 years. More than half of the participants were female $(51 \%)$ and $730(49 \%)$ were male and more than half $773(51.9 \%)$ participants had completed above level X of education. Majority 709(47.6\%) of the participants were service holders. Table 2 illustrates that majority $1289(84.6 \%)$ participants had heard about COVID-19, 1485(99.7\%) had heard about corona virus, 1428(95.9\%) knew that fever, dry cough and shortness of breath are the symptoms of COVID-19, 1155(77.6\%) participants knew that some patients may remain asymptomatic even after getting infected, $1311(88.0 \%)$ had the knowledge that COVID-19 can be fatal for those who are Elderly, Diabetic, 
Asthmatic or are having any Cardiovascular problems, $1106(74.3 \%)$ mentioned that death was not the ultimate fate of COVID-19, 1150(77.2\%) knew about quarantine, 1098(73.7\%) knew about isolation, 1412(94.8\%) had heard about social distancing, 1426(95.8\%) felt that it was necessary to maintain a minimum distance of 3 feet between two persons, 1406(94.4\%) had the knowledge that corona virus can enter into human body through mouth, nose and eyes, 1418(95.2\%) knew that corona virus can be transmitted through the coughing and sneezing, 1149(77.2\%) knew that corona virus can be transmitted through air, 1372(92.1\%) responded that Corona virus can be transmitted by touch (shaking hands, hugging, etc.), 1405(984.4\%) recognized that Corona virus can be transmitted at gatherings (marriage ceremonies, religious congregations, shopping malls, markets, etc.), 1455(97.0\%) acknowledged that Corona virus can be transmitted through travelling by public transport (buses, trains, launches, etc.), 1333(89.5\%) replied that Corona virus can be transmitted through fomites, goods, fruits, meat, fish, vegetables, etc., 1154(77.5\%) stated that Corona virus can be transmitted through dresses, cash (money bills), key rings, shoes etc., 1250(83.9\%) answered that Corona virus can be transmitted through different electronic devices like mobiles, laptops, headphones, etc., 1170(78.6\%) considered that Corona virus can be transmitted through sharing same toilet with COVID positive patient, only
$573(38.5 \%)$ replied that there was a definite treatment for COVID-19 disease, 901(60.5\%) mentioned that there no vaccine against this virus (rightly so, because at the time of collection of data, vaccine was under trail and yet to be approved), 1418(92.5\%) considered that regular cleaning of offices, homes, or class rooms with sanitizers can reduce the risk of infection, 1343(90.2\%) knew that corona virus transmission can be prevented by proper washing of food items (fish, meat, vegetables, etc.) prior to cooking, $995(66.8 \%)$ stated that there is more risk in eating half or semi cooked fish, meat, vegetables, etc., 1224(82.2\%) acknowledged that staying home can reduce the risk of transmission of corona virus, $1371(92.1 \%)$ avoided large public gathering like going to places of worship (mosques, temples, etc.), shopping malls, markets, etc., 1128(75.8\%) tried to avoid having contact with people like shaking hands, etc., 1300(87.3\%) skipped going to restaurants, $1173(78.8 \%)$ shied traveling by public transport recently, 996(66.9\%) had recently avoided or post-phoned visit to doctor's chamber or hospital, 1435(96.4\%) washed there dresses regularly after coming home from outside, $1320(88.7 \%)$ practiced disinfecting their shoes after come back from outside, 1251(84.0\%) stopped spending time with friends outside, 1384(92.9\%) maintained social distance and $1120(75.2 \%)$ answered that they avoided touching there mouth, eyes and nose with unwashed hands.

Table No 1: Demographic characteristics of the participants ( $n=1489)$

\begin{tabular}{|l|c|c|c|}
\hline \multicolumn{2}{|l|}{ Parameters } & Frequency & \multicolumn{2}{|c|}{ Percentage } \\
\hline Age (in years) (Mean \pm SD) & & \multicolumn{2}{|c|}{$28.81 \pm 8.64$} \\
\hline Range (min-max) & & 730 & 49.0 \\
\hline \multirow{3}{*}{ Sex } & Male & 759 & 51.0 \\
\cline { 2 - 4 } & Female & 67 & 4.5 \\
\hline Educational qualification & Illiterate & 97 & 6.5 \\
\cline { 2 - 4 } & Below V & 213 & 14.3 \\
\cline { 2 - 4 } & V - VIII & 339 & 22.8 \\
\cline { 2 - 4 } & IX - X & 773 & 51.9 \\
\cline { 2 - 4 } & Above X & 709 & 47.6 \\
\hline \multirow{5}{*}{ Professional status } & Service Holders & 460 & 30.9 \\
\cline { 2 - 4 } & Housewife & 207 & 13.9 \\
\cline { 2 - 4 } & Student & 94 & 6.3 \\
\cline { 2 - 4 } & Businessmen & 13 & 0.9 \\
\cline { 2 - 4 } & Daily laborer & 5 & 0.3 \\
\cline { 2 - 4 } & Unemployed & 1 & 0.1 \\
\cline { 2 - 4 }
\end{tabular}


Table No 2: Perceptive Component of the participants about COVID-19 ( $\mathrm{n}=1489)$

\begin{tabular}{|c|c|c|c|c|c|c|}
\hline \multirow[t]{2}{*}{ Perceptive component about COVID-19 } & \multicolumn{2}{|c|}{ Yes } & \multicolumn{2}{|c|}{ No } & \multicolumn{2}{|c|}{ Not Sure } \\
\hline & $\mathbf{n}$ & $\%$ & $\mathbf{n}$ & $\%$ & $\mathbf{n}$ & $\%$ \\
\hline Have you heard about COVID $-19 ?$ & 1289 & 84.6 & 181 & 12.2 & 49 & 3.3 \\
\hline Have you heard about corona virus? & 1485 & 99.7 & 2 & 0.1 & 2 & 0.1 \\
\hline $\begin{array}{l}\text { Fever, dry cough and shortness of breath are the symptoms of COVID- } \\
19 \text { ? }\end{array}$ & 1428 & 95.9 & 39 & 2.6 & 22 & 1.5 \\
\hline Do you know many patients may remain asymptomatic also? & 1155 & 77.6 & 221 & 14.8 & 113 & 7.6 \\
\hline $\begin{array}{l}\text { COVID-19 can be fatal in Elderly, Diabetic, Asthmatic and those with } \\
\text { Cardiovascular problems? }\end{array}$ & 1311 & 88.0 & 70 & 4.7 & 108 & 7.3 \\
\hline Is death the ultimate fate of COVID-19? & 304 & 20.4 & 1106 & 74.3 & 79 & 5.3 \\
\hline Do you know what quarantine is? & 1150 & 77.2 & 137 & 9.2 & 202 & 13.6 \\
\hline Do you know what isolation is? & 1098 & 73.7 & 176 & 11.8 & 215 & 14.4 \\
\hline Have you heard about social distancing? & 1412 & 94.8 & 33 & 2.2 & 44 & 3.0 \\
\hline $\begin{array}{l}\text { Do you feel it is important to keep a minimum distance of } 3 \text { feet between } \\
\text { two persons to prevent transmission? }\end{array}$ & 1426 & 95.8 & 39 & 2.6 & 24 & 1.6 \\
\hline Corona virus can enter into human body through mouth, nose and eyes? & 1406 & 94.4 & 22 & 1.5 & 61 & 4.1 \\
\hline $\begin{array}{l}\text { Corona virus can be transmitted through coughing and sneezing of the } \\
\text { patient? }\end{array}$ & 1418 & 95.2 & 26 & 1.7 & 45 & 3.0 \\
\hline Corona virus can be transmitted through air? & 1149 & 77.2 & 189 & 12.7 & 151 & 10.1 \\
\hline Corona virus can be transmitted by touch (handshaking, hugging, etc.)? & 1372 & 92.1 & 53 & 3.6 & 64 & 4.3 \\
\hline $\begin{array}{l}\text { Corona virus can be transmitted at gatherings like marriage ceremonies, } \\
\text { religious congregations, shopping malls, markets, etc. }\end{array}$ & 1405 & 94.4 & 37 & 2.5 & 47 & 3.2 \\
\hline $\begin{array}{l}\text { Corona virus can be transmitted through travelling by public transport } \\
\text { (buses, trains, launches, etc.). }\end{array}$ & 1445 & 97.0 & 19 & 1.3 & 25 & 1.7 \\
\hline $\begin{array}{l}\text { Corona virus can be transmitted through fomites, goods, fruits, meat, } \\
\text { fish, vegetables, etc. }\end{array}$ & 1333 & 89.5 & 45 & 3.0 & 111 & 7.5 \\
\hline $\begin{array}{l}\text { Corona virus can be transmitted through dresses, money (cash bills), key } \\
\text { rings, shoes etc. }\end{array}$ & 1154 & 77.5 & 171 & 11.5 & 164 & 11.0 \\
\hline $\begin{array}{l}\text { Corona virus can be transmitted through different electronic devices like } \\
\text { mobiles, laptops, headphones, etc. }\end{array}$ & 1250 & 83.9 & 115 & 7.7 & 124 & 8.3 \\
\hline $\begin{array}{l}\text { Corona virus can be transmitted through sharing same toilet with } \\
\text { COVID positive patient? }\end{array}$ & 1170 & 78.6 & 121 & 8.1 & 198 & 13.3 \\
\hline Is there any definite treatment for COVID-19 that you know of? & 573 & 38.5 & 766 & 51.4 & 150 & 10.1 \\
\hline Is there a vaccine against this virus? & 260 & 17.5 & 901 & 60.5 & 328 & 22.0 \\
\hline $\begin{array}{l}\text { Regular cleaning of offices, homes, or class rooms with sanitizer can } \\
\text { reduce the risk of corona virus infection? }\end{array}$ & 1418 & 95.2 & 48 & 3.2 & 23 & 1.5 \\
\hline $\begin{array}{l}\text { Corona virus transmission can be prevented by proper washing of fish, } \\
\text { meat, vegetables, etc. prior to cooking. }\end{array}$ & 1343 & 90.2 & 73 & 4.9 & 73 & 4.9 \\
\hline $\begin{array}{l}\text { There is more risk of transmission in eating half or semi cooked fish, } \\
\text { meat, vegetables, etc. }\end{array}$ & 995 & 66.8 & 280 & 18.8 & 214 & 14.4 \\
\hline Staying home can reduce the risk of transmission of corona virus? & 1224 & 82.2 & 89 & 6.0 & 176 & 11.8 \\
\hline $\begin{array}{l}\text { Do you avoid large public gatherings like going to places of worship, } \\
\text { shopping malls, etc. }\end{array}$ & 1371 & 92.1 & 81 & 5.4 & 37 & 2.5 \\
\hline Do you try to avoid shaking hands with people? & 1128 & 75.8 & 189 & 12.7 & 172 & 11.6 \\
\hline Have you recently avoided going to restaurants? & 1300 & 87.3 & 149 & 10.0 & 40 & 2.7 \\
\hline Do you avoid traveling by public transport recently? & 1173 & 78.8 & 301 & 20.2 & 15 & 1.0 \\
\hline $\begin{array}{l}\text { Have you recently avoided or post-phoned visit to doctor's chamber or } \\
\text { hospital? }\end{array}$ & 444 & 29.8 & 996 & 66.9 & 49 & 3.3 \\
\hline Do you wash your dress regularly after coming back from outside? & 1435 & 96.4 & 51 & 3.4 & 3 & 0.2 \\
\hline Do you disinfect your shoes when you come back from outside? & 1320 & 88.7 & 157 & 10.5 & 12 & 0.8 \\
\hline Do you regularly spend time with your friends outside? & 215 & 14.4 & 1251 & 84.0 & 23 & 1.5 \\
\hline Do you maintain social distance? & 1384 & 92.9 & 56 & 3.8 & 49 & 3.3 \\
\hline Do you frequently touch mouth, eyes and nose with unwashed hands? & 349 & 23.4 & 1120 & 75.2 & 20 & 1.3 \\
\hline
\end{tabular}

Table 3 shows $1435(96.4 \%)$ participants had the knowledge about different types of facemasks, $1119(75.2 \%)$ had hearkened about surgical face masks, only $807(54.2 \%)$ knew that facemasks can be reused, 1308(87.8\%) recognized that face masks can be made from fabrics /cloth at home, $1389(93.3 \%)$ felt that cloth face mask should be washed with detergent after every use, $1132(76.0 \%)$ recognized that face mask should not be shared between family members and friends, 1323(88.9\%) considered that wearing facemasks can prevent the spread of corona virus, $1357(91.1 \%)$ acknowledged that face masks protect from contracting COVID-19, 1006(67.6\%) 
knew there was a proper way (guidelines) for wearing a face mask, 1136(76.3\%) answered that surgical masks have a front and a back side, 1209(81.2\%) had heard about CDC recommendations about wearing facemask in public settings and 1172(78.7\%) responded that some countries have made it compulsory to use facemasks in public. Table 4 shows 941(62.3\%) participants thought there was an importance in using different types of facemasks, 845(56.7\%) didn't consider it is wise to reuse facemasks, $800(53.7 \%)$ thought cloth face mask could give protection against corona virus, 1139(76.5\%) thought that washing of facemask might kill corona virus on its surface if any, 1279 thought that it is better to wear personal facemasks in order to protect yourself and your family members and friends from the spread of COVID-19, $1103(74.1 \%)$ thought that wearing a facemask actually could help prevent the spread of the disease, $1260(84.6 \%)$ thought wearing a facemask protects you from contracting the virus, 1358 (91.2\%) thought it was important to wear a facemask properly, $1339(89.9 \%)$ thought it was advisable to check the front and back side of facemask before using it, 1455(97.7\%) thought it was important to wear a facemask in public places like markets, malls, religious congregations, etc., $1376(92.4 \%)$ thought it was important for the government to make it compulsory for everyone to use facemasks in public and 1391(93.4\%) thought we should encourage other to wear facemasks. Table 5 shows $887(59.6 \%)$ participants actually used different types of facemasks, $1318(88.5 \%)$ disposed face masks after regular interval, 942(63.3\%) didn't used home-made face masks, 1266(85.0\%) washed cloth facemask with detergent after using it every time, 1243(83.5\%) didn't share facemasks with family members and friends, 1361(91.4\%) participants wore facemasks to prevent the spread of disease to others, 1388(93.2\%) used facemasks to protect themselves from getting infected, 1129 (75.87\%) wore facemasks properly as per guide lines, 1392(93.5\%) covered both mouth and nose with facemask, 1461(98.1\%) wore a facemask when going outside in public places, $1228(82.5 \%)$ used facemasks to avoid punishment and 1394(93.6\%) encouraged other to wear facemasks.

Table No 3: Knowledge about importance of Facemasks for the prevention of transmission of COVID-19 $(\mathrm{n}=1489)$

\begin{tabular}{|l|l|l|l|l|l|l|}
\hline Knowledge about importance of Facemasks & Yes & \multicolumn{2}{l|}{ No } & \multicolumn{2}{l|}{ Not Sure } \\
\cline { 2 - 7 } & $\mathbf{n}$ & $\mathbf{\%}$ & $\mathbf{n}$ & $\mathbf{\%}$ & $\mathbf{n}$ & $\mathbf{\%}$ \\
\hline Do you know there are many different types of facemasks? & 1435 & 96.4 & 21 & 1.4 & 33 & 2.2 \\
\hline Have you heard about surgical facemask? & 1119 & 75.2 & 283 & 19.0 & 87 & 5.8 \\
\hline Do you know that facemasks can be reused? & 807 & 54.2 & 574 & 38.5 & 108 & 7.3 \\
\hline Do you know facemasks can be made from fabrics /cloth at home? & 1308 & 87.8 & 123 & 8.3 & 58 & 3.9 \\
\hline $\begin{array}{l}\text { Do you know cloth facemasks should be washed with detergent } \\
\text { ffter every use? }\end{array}$ & 1389 & 93.3 & 45 & 3.0 & 55 & 3.7 \\
\hline $\begin{array}{l}\text { Do you know that face masks shouldn't be shared between family } \\
\text { members and friends? }\end{array}$ & 1132 & 76.0 & 307 & 20.6 & 50 & 3.4 \\
\hline $\begin{array}{l}\text { Do you know wearing facemasks can help prevent the spread of } \\
\text { corona virus? }\end{array}$ & 1323 & 88.9 & 73 & 4.9 & 93 & 6.2 \\
\hline Do you know facemasks protects you from contracting COVID-19? & 1357 & 91.1 & 59 & 4.0 & 73 & 4.9 \\
\hline $\begin{array}{l}\text { Do you know there is a proper way (guidelines) for wearing a } \\
\text { facemask? }\end{array}$ & 1006 & 67.6 & 223 & 15.0 & 260 & 17.5 \\
\hline Do you know that surgical masks have a front and a back side? & 1136 & 76.3 & 153 & 10.3 & 200 & 13.4 \\
\hline $\begin{array}{l}\text { Have you heard about CDC recommendations about wearing } \\
\text { facemasks in public settings? }\end{array}$ & 1209 & 81.2 & 122 & 8.2 & 158 & 10.6 \\
\hline $\begin{array}{l}\text { Do you know that some countries have made it compulsory to use } \\
\text { facemasks in public? }\end{array}$ & 1172 & 78.7 & 132 & 8.9 & 185 & 12.4 \\
\hline
\end{tabular}


Table 4: Attitude of participants about importance of Facemasks for the prevention of transmission COVID$19(n=1489)$

\begin{tabular}{|l|c|c|c|c|c|c|}
\hline \multirow{2}{*}{ Attitude about use of Facemasks } & \multicolumn{2}{|c|}{ Yes } & \multicolumn{2}{c|}{ No } & \multicolumn{2}{c|}{ Not Sure } \\
\cline { 2 - 7 } & $\mathbf{n}$ & $\mathbf{\%}$ & $\mathbf{n}$ & $\mathbf{\%}$ & $\mathbf{n}$ & $\mathbf{\%}$ \\
\hline $\begin{array}{l}\text { Do you think there is any importance in using different types } \\
\text { of facemasks? }\end{array}$ & 941 & 62.3 & 317 & 21.3 & 231 & 15.5 \\
\hline Do you think it is wise to reuse facemasks? & 503 & 33.8 & 845 & 56.7 & 141 & 9.5 \\
\hline $\begin{array}{l}\text { Do you think cloth facemasks can give you protection against } \\
\text { corona virus? }\end{array}$ & 800 & 53.7 & 413 & 27.7 & 276 & 18.5 \\
\hline $\begin{array}{l}\text { Do you think that washing of facemasks kill corona virus on } \\
\text { its surface if any? }\end{array}$ & 1139 & 76.5 & 167 & 11.2 & 183 & 12.3 \\
\hline $\begin{array}{l}\text { Do you think you should wear personal facemasks in order to } \\
\text { protect yourself and your family members and friends from } \\
\text { spread of COVID-19? }\end{array}$ & 1279 & 85.9 & 176 & 11.8 & 34 & 2.3 \\
\hline $\begin{array}{l}\text { Do you think that wearing a facemask actually can help } \\
\text { prevent the spread of the disease? }\end{array}$ & 1103 & 74.1 & 237 & 15.9 & 149 & 10.0 \\
\hline $\begin{array}{l}\text { Do you think wearing a facemask protects you from } \\
\text { contracting the infection? }\end{array}$ & 1260 & 84.6 & 59 & 4.0 & 170 & 11.4 \\
\hline Do you think it is important to wear a facemask properly? & 1358 & 91.2 & 66 & 4.4 & 65 & 4.4 \\
\hline $\begin{array}{l}\text { Do you think it is advisable to check the front and back side of } \\
\text { your facemask before using it? }\end{array}$ & 1339 & 89.9 & 84 & 5.6 & 66 & 4.4 \\
\hline $\begin{array}{l}\text { Do you think it is important to wear a facemask in public } \\
\text { places like markets, malls, religious congregations, etc.? }\end{array}$ & 1455 & 97.7 & 28 & 1.9 & 6 & 0.4 \\
\hline $\begin{array}{l}\text { Do you think it is important for the government to make it } \\
\text { compulsory for everyone to use facemasks in public? }\end{array}$ & 1376 & 92.4 & 50 & 3.4 & 63 & 4.2 \\
\hline Do you think we should encourage other to wear facemasks? & 1391 & 93.4 & 74 & 5.0 & 24 & 1.6 \\
\hline
\end{tabular}

Table 5: Practice of participants about importance of Facemasks for the prevention of transmission of COVID-19 ( $\mathrm{n}=1489)$

\begin{tabular}{|l|c|c|c|c|c|c|}
\hline \multirow{2}{*}{ Practice about use of Facemasks } & \multicolumn{2}{|c|}{ Yes } & \multicolumn{2}{c|}{ No } & Not Sure \\
\cline { 2 - 7 } & $\mathbf{n}$ & $\mathbf{\%}$ & $\mathbf{n}$ & $\mathbf{\%}$ & $\mathbf{n}$ & $\mathbf{\%}$ \\
\hline Do you use different types of facemasks? & 887 & 59.6 & 586 & 39.4 & 16 & 1.1 \\
\hline Do you dispose your facemasks after regular interval? & 1318 & 88.5 & 149 & 10.0 & 22 & 1.5 \\
\hline Do you use home-made facemasks? & 524 & 35.2 & 942 & 63.3 & 23 & 1.5 \\
\hline $\begin{array}{l}\text { Do you wash your cloth facemasks with detergent after using it } \\
\text { every time? }\end{array}$ & 1266 & 85.0 & 177 & 11.9 & 45 & 3.0 \\
\hline Do you share facemasks with your family members and friends? & 233 & 15.6 & 1243 & 83.5 & 13 & 0.9 \\
\hline Do you wear facemasks to prevent spread of disease to others? & 1361 & 91.4 & 90 & 6.0 & 38 & 2.6 \\
\hline $\begin{array}{l}\text { Do you use facemasks to protect yourself from corona virus } \\
\text { infection? }\end{array}$ & 1388 & 93.2 & 46 & 3.1 & 55 & 3.7 \\
\hline Do you wear facemasks properly as per guide lines? & 1129 & 75.8 & 252 & 16.9 & 108 & 7.3 \\
\hline Do you cover both mouth and nose with your facemask? & 1392 & 93.5 & 95 & 6.4 & 2 & 0.1 \\
\hline $\begin{array}{l}\text { Do you practice use of facemasks after checking front and back } \\
\text { side? }\end{array}$ & 1324 & 88.9 & 146 & 9.8 & 19 & 1.3 \\
\hline Do you use facemasks to avoid punishment? & 230 & 15.4 & 1228 & 82.5 & 31 & 2.1 \\
\hline Do you encourage other to wear facemask? & 1394 & 93.6 & 70 & 4.7 & 24 & 1.6 \\
\hline
\end{tabular}

Knowledge, Attitude and Practice of the participants about the importance of face masks to control COVID-19 was assessed by questionnaire based interviewing. Questions were constructed in a manner that the answers were recorded as yes, not sure and no, and the correct responses got 2, not sure 1 and incorrect 0.12 questions each were asked to assess Knowledge, Attitude and Practice, and each variable was divided into good (score $\geq 15$ ), moderate (score 8-15) and poor (score $\leq 7)$. Table 6 shows association between knowledge to attitude of the participants towards use of facemasks, findings of which were statistically significant ( $\mathrm{p}<0.001)$. It showed that 93.08\% (1386) participants had good knowledge score, while $6.85 \%$ (102) participants had moderate knowledge and meager 01 had poor knowledge about facemasks.93.825 
participants had good attitude about the importance of using facemasks, while 92 showed a moderate attitude and none showed poor attitude towards using facemasks. 88.72\% (1321) showed a good knowledge-good attitude score, 65 (4.37\%) had a good knowledge- moderate attitude score, $5.10 \%$ (76) participants evinced moderate knowledge- good attitude score and 26 (1.75\%) showed a moderate knowledge- moderate attitude score. Table 7 shows association between knowledge to practice of the participants towards importance of using facemasks, findings of which were statistically significant ( $\mathrm{p}<0.001)$. It showed that $1386(93.08 \%)$ participant had good knowledge about facemasks while 102 (6.85\%) had moderate knowledge and meager 01 had poor knowledge about the importance of using facemasks. 1250 (83.94\%) participants had good practice of using facemasks, while 237 (15.92\%) showed a moderate practice score and 02 poor practice of using facemasks. 78.44\% (1168) showed a good knowledge-good practice score, none of the participants scored a poor knowledgepoor practice score, only 218 (14.64\%) participant had a good knowledge- moderate practice score, and $82(5.51 \%)$ participants scored a moderate knowledge-good practice. Pearson correlation between knowledge and attitude was 0.477 and between knowledge and practice was 0.304 , all the values where statistically significant for $\mathrm{p}$ value $<0.001$.

Table No 6: Association of Knowledge and Attitude of the participants about the importance of using facemasks.

\begin{tabular}{|l|c|c|c|c|c|}
\hline \multirow{2}{*}{$\begin{array}{l}\text { Attitude about } \\
\text { Facemasks }\end{array}$} & \multicolumn{2}{|c|}{ Knowledge about Facemasks } & Total & $\begin{array}{c}\text { Pearson } \\
\text { correlation } \\
\text { coefficient }\end{array}$ \\
\cline { 2 - 5 } & Good Knowledge & $\begin{array}{c}\text { Moderate } \\
\text { Knowledge }\end{array}$ & $\begin{array}{c}\text { Poor } \\
\text { Knowledge }\end{array}$ & & \multirow{2}{*}{0.477} \\
\hline Good Attitude & $1321(88.72 \%)$ & $76(5.10 \%)$ & $00(00.00 \%)$ & $1397(93.83 \%)$ & \\
\hline Moderate Attitude & $65(4.37 \%)$ & $26(1.75 \%)$ & $01(0.07 \%)$ & $92(6.18 \%)$ & $00(00.00 \%)$ \\
\hline Poor Attitude & $00(00.00 \%)$ & $00(00.00 \%)$ & $00(00.00 \%)$ & 1489 & \\
\hline Total & $1386(93.08 \%)$ & $102(6.85 \%)$ & $01(0.07 \%)$ & & \\
\hline
\end{tabular}

Table No 7: Association of Knowledge and Practice of the participants about the importance of using facemasks.

\begin{tabular}{|l|c|c|c|c|c|}
\hline \multirow{2}{*}{$\begin{array}{l}\text { Practice about } \\
\text { Facemasks. }\end{array}$} & \multicolumn{2}{|c|}{ Knowledge about Facemasks } & Total & $\begin{array}{l}\text { Pearson } \\
\text { correlation } \\
\text { coefficient }\end{array}$ \\
\cline { 2 - 5 } & Good Knowledge & $\begin{array}{c}\text { Moderate } \\
\text { Knowledge }\end{array}$ & $\begin{array}{c}\text { Poor } \\
\text { Knowledge }\end{array}$ & \\
\hline Good Practice & $1168(78.44 \%)$ & $82(5.51 \%)$ & $00(00.00 \%)$ & $\begin{array}{c}1250 \\
(83.94 \%)\end{array}$ & \multirow{2}{*}{0.304} \\
\cline { 1 - 5 } $\begin{array}{l}\text { Moderate } \\
\text { Practice }\end{array}$ & $218(14.64 \%)$ & $18(1.21 \%)$ & $01(0.07 \%)$ & $237(15.92 \%)$ & $02(0.13 \%)$ \\
\hline Poor Practice & $00(00.00 \%)$ & $02(0.13 \%)$ & $00(00.00 \%)$ & 1489 & \\
\hline Total & $1386(93.08 \%)$ & $102(6.85 \%)$ & $01(0.07 \%)$ & \\
\hline
\end{tabular}

\section{Discussion}

Bangladesh, a low middle-income country and one of the most densely populated one in the world has slipshod to combat COVID-19. Success in this battle is partly determined by the knowledge and behavioral changes of the general population as well as how effectively these nonpharmacological control measures are being implemented and thereafter abided by the citizens. This study was conducted aiming at measuring the level of knowledge for COVID-19 and knowledge, attitude and practices involved in the proper use of facemasks as an essential preventive measure in regard to the disease. Among 1489 participants in this study, the mean age was $28.81 \pm 8.64$ years with range from 12 to 70 years. Of all respondents, $41.9 \%$ were between the ages of 20-31 years. More than half of the participants were female $(51.0 \%)$ and $730(49.0 \%)$ were male. More than half $773(51.9 \%)$ participants had 
completed above $\mathrm{X}$ education level. Majority 709(47.6\%) participants were service holders. In a study by Rahman SMM, et al. ${ }^{21}$ they showed that $30.0 \%$ of respondents had completed their graduation, $29.0 \%$ were students, $16.2 \%$ were housewives and $9.5 \%$ were unemployed.

Karim A, et al. ${ }^{22}$ reported that the percentages of participants having good knowledge about COVID-19 were $57.6 \%, 75.1 \%$, and $95.8 \%$ over phone $(n=1426)$, online non-medical participants $(\mathrm{n}=1097)$, and online medical participants $(\mathrm{n}=382)$, respectively. In that online survey, a total of 1521 participated amongst whom $98.6 \%$ (1500) had heard about COVID-19. The correct response rates to the 20 knowledge questions ranged from $54.3-99.1 \%, 64-99.6 \%, 71.1-99.9 \%$, and $88-100 \%$ over phone (unadjusted), over phone (adjusted to online non-medical), online non-medical, and online medical participants respectively. Kakemam E, et al. ${ }^{23}$ reported that the majority of respondents $(84.5 \%)$ had heard about COVID-19. Overall, $84.5 \%$ of respondents were aware that it is possible to survive and recover from it. Almost $60 \%$ of respondents perceived themselves to be at some risk of contracting COVID-19. In an openended question, the most common cause of coronavirus disease was "virus" (94.4\%); only $31.7 \%$ linked coronavirus to a "bats, monkeys, and wild animals." Very few respondents mentioned that coronavirus was caused by "Bacteria" (6.7\%), "Evildoing/Sin" (4.1\%), or "Parasites" (3.7\%). Our study showed that majority of the participants had a good knowledge about COVID-19 and its causative agent, depicted from the questions asked to the participants the result of which is given in Table 2. 95.9\% of the participants knew about the main symptoms of the disease, more than $90 \%$ answered correctly for modes of transmission, $88 \%$ thought it was a risk factor for elderly and those with comorbidities. Kakemam E, et al. ${ }^{23}$ reported that the most frequently cited modes of transmission was shaking hands with an infected person (91.9\%), kissing and hugging $(90.1 \%)$, and being in contact with the saliva of an infected person. Overall,
$80 \%$ of respondents could state three key signs/ symptoms of the disease: "difficulty breathing" (97.7\%), "fever" (97.6), and "cough" (94.3\%). Rahman MM, et al. ${ }^{24}$ observed many respondents $(54.06 \%)$ reported unexpected responses to questions regarding main clinical symptoms (fever, fatigue and dry cough) of COVID-19 and development of severe form of illness in elderly people with co-morbidities. Most participants responded expectedly to questions regarding knowledge about any cure to recover from COVID-19 (68.99\%), spread of infection may occurs from the pre-symptomatic or asymptomatic persons with COVID-19 and also through contact with the infected one $(77.92 \%)$, mode of transmission is via respiratory droplets of infected person $(61.04 \%)$, wear general medical mask, avoid crowded places, regular wash of hands can prevent contraction of infection (95.78\%), and minimum preventive measures were fine for children and young adults was wrong action to prevent spread of COVID-19 infection (60.23\%). In South Korea a similar study done by Lee M, et al. ${ }^{10}$ showed comparably similar results, $93.2 \%$ knew that the mode of transmission of this disease is through respiratory droplets. Further in that study it was also noticed that $42.2 \%$ participants had a misunderstanding that the infection could occur through eating or having wild animals. Ferdous MZ, et al. ${ }^{25}$ evaluated the perception component in the participants and found $93.7 \%$ participants thought the virus spreads through close contact with infected persons, $66.4 \%$ thought that it occurs as direct transmission through coughing, $61.3 \%$ thought that touching contaminated surfaces is one of the causes of spread of infection while only $0.5 \%$ had no idea about the mode of transmission. Their study also found that $99.4 \%$ had a knowledge about common symptoms (fever, dry cough, shortness of breath, etc.). They further reported $86.1 \%$ participants thought that it was fatal in older age and $74.6 \%$ knew that cancer, Diabetes, Chronic Renal disease patients are at higher risk. AlHanawi et al. $^{26}$ reported that $98 \%$ participants 
were well aware of COVID-19 symptoms but only $50 \%$ thought that the spread may occur when in close proximity with infected patient. They further mentioned in their study that $96 \%$ of the participants knew about the clinically approved treatment (as of the date of that manuscript), while in our study it was found that $766(51.4 \%$ ) replied that there was no definite treatment for COVID-19 disease, 901(60.5\%) mentioned that there no vaccine against this virus (rightly so, because at the time of collection of data vaccine was under trail). These findings were also consistent with the studies of Zhong BL,et al. ${ }^{27}$ conducted among the Chinese residents and of Alzoubi $\mathrm{H}$ et al. $^{28}$ conducted among the students in Jordan. Their knowledge regarding the availability of vaccines and treatment wasalso similar to other studies. AlHanawi et al. ${ }^{26}$ reported that $95 \%$ refrained from attending social events, 94\% participants avoided crowded places and $88 \%$ avoided shaking hands, compared to our study in which $92.1 \%$ avoided large public gathering, $75.8 \%$ tried to avoid having contact with people like shaking hands, etc., $87.3 \%$ skipped going to restaurants, $78.8 \%$ shied traveling by public transport recently, $66.9 \%$ had recently avoided visiting a doctor. Kakemam $\mathrm{E}$, et $\mathrm{al}^{23}$ reported that the knowledge of prevention and treatment was higher among respondents in their study as nearly everyone knew that the spread of this disease can be prevented by staying at home, reducing contact with people $(95.3 \%)$ as well as constant hand washing and using disinfectants (92.5\%). 75.1\% of respondents expressed that early treatment of coronavirus could increase survival and reduce the chance of transmission within the household.

The Knowledge, Attitude and Practices regarding importance of using facemasks in the prevention and control of COVID-19 has not been reported comprehensively as has been in this study. For each question of knowledge, the distribution of responses from the participants is presented in Table 3, while attitude component are mentioned in Table 4 and practices component in Table 5. Al-Hanawi et al. ${ }^{26}$ reported that the score of the knowledge component in the study population was 17.96 ( $\mathrm{SD}=2.24$, Range 3-22) and the overall accuracy rate was 81.64 indicating good knowledge. Mean attitude score was 28.23 ( $\mathrm{SD}=2.76$, Range 6-30) indicating good attitude and mean score for practice $4.34 \quad(\mathrm{SD}=0.89$, Range $=0-5$ ) which too indicated good practice. 49 $\%$ of the participants had little knowledge about when, whom and what are the different types of facemasks. Ferdous MZ, et al. ${ }^{25}$ in their study reports $87.2 \%$ of the participants knew that using facemasks, 93.5\% knew that washing hands with soap and water, maintaining social distance (93.5\%) and avoiding touching the eyes, nose with hands $(90.4 \%)$ were preventive measures against COVID-19. Erfani AH et al. ${ }^{29}$ conducted a study in Iran and claimed that the study population had a moderate knowledge (46.5\% and 56.2\%) about COVID-19 and personal hygiene and observed that mean knowledge score was 48.8, they added that mean correct answer score for attitude was 40.6 ( $\mathrm{SD}=2.4$, Range 15-45) and average correct answer score of the 12 questions regarding COVID-19 and personal hygiene practices was 32.1 ( $\mathrm{SD}=2.9$, Range12-36), establishing a moderate practice of the participants. Rahman $\mathrm{MM}$, et al. ${ }^{24}$ also revealed majority of the respondents (more than 90\%) reported good practices to prevent COVID-19 infection. However, many respondents (26.30\%) lacked practice to avoid touching their eyes, nose and mouth to prevent the main route of Coronavirus into human body. Altaheret al. ${ }^{30}$ reported most of the participants had a high level of personal hygiene and healthy practices during the COVID19 outbreak. Lee $\mathrm{M}$ et al. ${ }^{10}$ found that $48.8 \%$ thought that general medical mask helps prevent spread of Corona Virus. They also found that the most frequently performed practices was wearing a facemask $(\mathrm{M}=3.82, \mathrm{SD}=0.49)$, then hand sanitization $(\mathrm{M}=3.51, \quad \mathrm{SD}=0.66)$ and social distancing $(\mathrm{M}=3.11, \mathrm{SD}=0.90)$.

Table 6 and Table 7 of the study describes the relation of knowledge to attitude and knowledge to practices of the participants toward using 
facemasks respectively. It was seen that those who had higher knowledge about the importance of using facemasks displayed a higher efficacy belief for facemasks hence practiced using it as per guidelines. Lee $\mathrm{M}$, et al. ${ }^{10}$, in their study had reported similar observation, that higher knowledge was associated with higher attitude and practices for personal hygiene that included wearing of facemask and practicing hand hygiene. Influence of Knowledge and Attitude on practices for those with higher knowledge were more likely to wear mask $(\beta=0.31, \mathrm{P}<0.001)$ and similar for Hand hygiene $(\beta=0.20, \mathrm{P}<0.001)$. Erfani $\mathrm{AH}$, et al. $^{29}$ states that based on the data and the score of the participants, there was a significant association among the participants Knowledge, Attitude and Practices $(\mathrm{P}<0.001)$. Rahman $\mathrm{MM}$, et $\mathrm{al}^{24}$ reported that the majority of the respondents reported positive attitudes and strongly agreed on the importance of measures towards COVID-19, such as lock-down (74.3\%), followed by maintaining personal hygiene $(65.7 \%)$, home quarantine $(52 \%)$, isolation and treatment of infected people $(51.3 \%)$, with significantly higher $(\mathrm{p}<0.01)$ positive attitude among urban respondents compared to rural respondents. Regarding attitude scores, $84.9 \%$ of the urban respondents had a significantly higher positive attitude $(\mathrm{p}<0.01)$ compared to rural respondents. The majority of the respondents (88.8\%) identified staying away from the infected person as a good preventive practice against COVID-19 infection, followed by frequent hand washing using hand sanitizer (83.2\%), avoiding touching nose, mouth, and eyes (78.2\%), using a face mask (77.6\%), practicing self-isolation/home quarantine (88\%), and avoiding hugging (75.7\%). Significantly higher responses about preventive practices of COVID-19 infection such as (57.7\%) practicing respiratory hygiene (facemasks), and maintaining social distance (min. 1 meter) (56.4\%) were more common among urban respondents compared to rural respondents ( $\mathrm{p}<$ 0.01 ), except for avoiding handshake (50.3\%). Regarding overall practice scores, only $32.5 \%$ of the urban respondents had good preventive practices against COVID-19, though these were significantly higher compared to rural respondents $(22 \%)(\mathrm{p}<0.01)$. In this study it was observed that the association of knowledge and attitude about using facemasks and association between knowledge and practice was almost identic. Pearson correlation between Knowledge-Attitude for using facemask was 0.477 and Pearson correlation between Knowledge-Practice of the participants was 0.303. All the values were statistically significant for $p$ value $<0.001$. A study on a Malaysian community by $\mathrm{Li} \mathrm{H}$, et al. ${ }^{31}$ has reported an overall rate of the knowledge of $80.5 \%$, and most participants (83.1\%) demonstrated positive attitudes toward the prevention of COVID-19.

\section{Conclusion}

Our findings suggest that Bangladeshi population demonstrated a decent Knowledge about COVID19, and the Knowledge about the importance using facemasks in preventing the spread of the disease was good and that too translated on attitude and practices. These factors might attribute to not so exponential spread as was expected being it one of the most density populated and low middle socioeconomic income country. Further strictly using the facemask and abiding by the guidelines is essential for appropriate control, prevent further surge and future consecutive waves and preventing community transmission of the corona virus is necessary which might help easing restrictions like lockdown, closing educational institutions, etc. by the government. Awareness campaigning on social media and mass media platforms should be done more aggressively. Health education directed to the vulnerable population by the development of effective health education programmes that incorporate considerations of KAP modifying factors is the need of the time. Programme that change the attitude and encourage the practice of hand hygiene need to be enforced 
to close the gap of KAP towards COVID-19 and its preventive measures.

\section{Limitations}

Only a smaller region of Bangladesh was used for taking the sample, which doesn't represent the whole country. Data used in this analysis were self-reported hence might suffer reporting bias. There were a limited number of questions used to measure the level of knowledge, attitude and practice. In-depth interviews and focused group discussions is required to accurately access the level of attitude and practices of an individual. More than half $(54.9 \%)$ of the study population had the educational qualification of more than $\mathrm{X}$ standard, which does not represent the true picture of Bangladesh, hence might be the reason for better results in this study.

\section{Recommendations}

Community based national survey is most appropriate to cover all the regions of the country. General health education aiming to improve the knowledge and thereby leading to a more favorable attitude and practices is the need during this challenging period.

\section{Acknowledgement}

We thank all the study participants for their voluntary participation and for providing essential information.

\section{References}

1. Wu F, Zhao S, Yu B, Chen Y-M, Wang $\mathrm{W}$, Song Z-G, et al. A new coronavirus associated with human respiratory disease in China. Nature. (2020) 579:265-9. doi: 10.1038/s41586-020-2008-3

2. Zhou P, Yang X-L, Wang X-G, Hu B, Zhang L, Zhang W, et al. A pneumonia outbreak associated with a new coronavirus of probable bat origin. Nature. (2020) 579:270-3. doi: 10.1038/s41586020-2012-7
3. Riou J, Althaus CL. Pattern of early human-to-human transmission of Wuhan 2019 novel coronavirus (2019-nCoV), December 2019 to January 2020. Euro surveillance. (2020) 25:2000058. doi: 10.2807/1560-7917.ES.2020.25.4.2000058

4. Chan JF-W, Yuan S, Kok K-H, To KK-W, Chu H, Yang J, et al. A familial cluster of pneumonia associated with the 2019 novel coronavirus indicating person-to-person transmission: a study of a family cluster. Lancet. (2020) 395:514-23. doi: 10.1016/S0140-6736(20)30154-9

5. Al-Hanawi MK, Angawi K, Alshareef N, Qattan AMN, et al. (2020) Knowledge, Attitude and Practice Toward COVID-19 Among the Public in the Kingdom of Saudi Arabia: A Cross-Sectional Study. Front. Public Health 8:217. doi: 10.3389/fpubh.2020.00217

6. WHO: Statement on the second meeting of the International Health Regulations Emergency Committee regarding the outbreak of novel coronavirus (2019nCoV), Geneva, Switzerland, 30 January 2020. 2005. In.; 2020.

7. Tang D, Tou J, Wang J, Chen Q, Wang W, Huang $J$, et al. Prevention and control strategies for emergency, limited-term, and elective operations in pediatric surgery during the epidemic period of COVID-19. World J Pediatr Surg. (2020) 3:e000122. doi: 10.1136/wjps-2020-000122

8. WHO. Coronavirus disease 2019 (COVID19) WHO Health Emergency Dashboard 15 May 2021.

9. Institute of Epidemiology DCaRI. Covid19 Status Bangladesh. 2020. https://www.iedcr.gov.bd/. Accessed 2 May 2020.

10. Lee M, Kang BA and You M. Knowledge, attitudes, and practices (KAP) toward COVID-19: a cross-sectional study in South Korea. BMC Public Health (2021) 21:295.doi: 10.1186/s12889-021-10285-y 
11. Ajilore K, Atakiti I, Onyenankeya K. College students' knowledge, attitudes and adherence to public service announcements on Ebola in Nigeria: Suggestions for improving future Ebola prevention education programmes. Health Education Journal. 2017; 76(6):648-60. Epub 2017/10/01.

12. Tachfouti N, Slama K, Berraho M, Nejjari C. The impact of knowledge and attitudes on adherence to tuberculosis treatment: a case-control study in a Moroccan region. The Pan African medical journal. 2012; 12:52. Epub 2012/09/01.

13. Bell DM. Public health interventions and SARS spread, 2003. Emerging Infectious Diseases. 2004; 10(11):1900-6. Epub 2004/11/20.

14. Lee M, You M. Psychological and behavioral responses in South Korea during the early stages of coronavirus disease 2019 (COVID-19). Int J Environ Res Public Health. 2020; 17(9):2977.

15. Anderson RM, Heesterbeek H, Klinkenberg D, Hollingsworth TD. How will country-based mitigation measures influence the course of the COVID-19 epidemic? Lancet. 2020; 395(10228):9314.

16. Ferguson N, Laydon D, NedjatiGilani G, et al Report 9: impact of nonpharmaceutical interventions (NPIs) to reduce COVID19 mortality and healthcare demand; 2020.

17. Papagiannis D, Malli F, Raptis DG, et al. Assessment of knowledge, attitudes, and practices towards new coronavirus (SARSCoV-2) of health care professionals in Greece before the outbreak period. Int $\mathbf{J}$ Environ Res Public Health. 2020; 17(14):4925.

18. Afzal MS, Khan A, Qureshi UUR, et al. Community-based assessment of knowledge, attitude, practices and risk factors regarding COVID-19 among
Pakistanis residents during a recent outbreak: a cross-sectional survey. J Community Health. 2020:1-11.

19. Alrubaiee GG, Al-Qalah TAH, Al-Aawar MSA. Knowledge, attitudes, anxiety, and preventive behaviours towards COVID-19 among health care providers in Yemen: an online cross-sectional survey. BMC Public Health. 2020; 20(1):1541.

20. Tamang N, Rai P, Dhungana S, et al. COVID-19: a National Survey on perceived level of knowledge, attitude and practice among frontline healthcare Workers in Nepal. BMC Public Health. 2020; 20(1):1905.

21. Rahman SMM, Akter A, Mostari KF, Ferdousi S, Ummon IJ, Naafi SM, Rahman MM. Assessment of knowledge, attitudes and practices towards prevention of coronavirus disease (COVID-19) among Bangladeshi population. Bangladesh Med Res Counc Bull 2020; 46: 73-82

22. Karim A, Akter M, Mazid AHMT, Pulock OS, Aziz TT, Hayee S et al. Knowledge and attitude towards COVID-19 in Bangladesh: Population-level estimation and a comparison of data obtained by phone and online survey methods.2020 doi:

https://doi.org/10.1101/2020.05.26.201044 97.

23. Kakemam E, Ghoddoosi-Nejad D, Chegini $\mathrm{Z}$, Momeni $\mathrm{K}$, Salehiniya $\mathrm{H}$, et al. Knowledge, Attitudes, and Practices Among the General Population During COVID-19 Outbreak in Iran: A National Cross-Sectional Online Survey. Frontiers in Public Health. 2020;8.

24. Rahman MM, Khan SJ, Sakib MS, Halim MA, Rahman F, Rahman MM, et al. COVID-19 responses among general people of Bangladesh: Status and individual view toward COVID-19 during 
lockdown period. Cogent Psychology. 2021 Jan 1;8(1):1860186.

25. Ferdous M.Z, Islam M.S, Sikder M.T, Mosaddek ASM., Zegarra-Valdivia JA, Gozal D (2020) Knowledge, attitude, and practice regarding COVID-19 outbreak in Bangladesh: An online based crosssectional study. PLoS ONE 15(10): e0239254. https://doi.org/10.1371/journal. pone. 0239254

26. Al-Hanawi MK, Angawi K, Alshareef N, Qattan AMN, Helmy HZ, et al. (2020) Knowledge, Attitude and Practice Toward COVID-19 Among the Public in the Kingdom of Saudi Arabia: A CrossSectional Study. Front. Public Health 8:217. doi: 10.3389/fpubh.2020.00217

27. Zhong BL, Luo W, Li HM, Zhang QQ, Liu XG, Li WT, Li Y. Knowledge, attitudes, and practices towards COVID-19 among Chinese residents during the rapid rise period of the COVID-19 outbreak: a quick online cross-sectional survey. International journal of biological sciences. 2020;16(10): 1745.

28. Alzoubi H, Alnawaiseh N, Al-Mnayyis A, Abu- Lubad M, Aqe A, Hani Al-Shagahin H. COVID-19- knowledge, attitude and practice among Medical and Non-Medical University students in Jordan. J Pure Appl. Microbiol. 2020;14, 17-24.

29. Erfani A, Shahriarirad R, Ranjbar K, Mirahmadizadeh A \&Moghadami M. Knowledge, Attitude and Practice toward the Novel Coronavirus (COVID-19) Outbreak: A Population-Based Survey in Iran. [Preprint]. Bull World Health Organ. E-pub: 30 March 2020. doi: http://dx.doi.org/10.2471/BLT.20.256651.

30. Altaher AM, Elottol AE, Jebril MA, Aliwaini SH. Assessment of awareness and hygiene practices regarding COVID19 among adults in Gaza, Palestine. New Microbes and New Infections. 2021 May 1;41:100876.
31. Li H, S.M. Liu, X.H. Yu, S.L. Tang, C.K. Tang Coronavirus disease 2019 (COVID19): current status and future perspectives. Int J Antimicrob Agents (2020), 10.1016/j.ijantimicag.2020.105951 